\title{
DETECTION OF URER AND UREC AMONG PROTEUS MIRABILIS
}

\author{
ABDUL KAREEM MUNEER ALATRASH, AHLAM KADHUM AL-YASSEEN*
}

Department of Biology, Faculty of Education for Girls, University of Kufa, Iraq. Email: ezatahlam@yahoo.com

Received: 07 April 2017, Revised and Accepted: 10 May 2017

ABSTRACT

Objective: This study aimed to investigate the correlation between ureR and ureC genes with the production of urease by Proteus mirabilis.

Methods: A total of 450 mid-stream urine samples have been collected from patients with urinary tract infection whom admitted to the hospitals in Annajaf Al-Ashraf province for consultancy during the period from October 2015 to February 2016.0 ut of 150 bacterial isolates, only 29 isolates were belong to $P$. mirabilis according to conventional methods (depending on microscopic and culturing examination as well as biochemical test) and molecular technique using 16SrRNA gene.

Results: The results of phenotypic and genotypic detection of urease in $P$. mirabilis showed that all isolates were able to produce urease and possess ureR and ureC that encodes to urease by appearing of amplicon with molecular weight 359 and 533 bp, respectively, when electrophoresed on $1 \%$ agarose gel.

Conclusion: A correlation has been found between ureR and ureC genes with the production of urease by $P$. mirabilis.

Keywords: Urease, Proteus mirabilis, ureR, ureC, Polymerase chain reaction technique.

(C) 2017 The Authors. Published by Innovare Academic Sciences Pvt Ltd. This is an open access article under the CC BY license (http://creativecommons. org/licenses/by/4. 0/) DOI: http://dx.doi.org/10.22159/ajpcr.2017.v10i8.18987

\section{INTRODUCTION}

Proteus is a Gram-negative, anaerobic rods belongs to the family Enterobacteriaceae and has more than four species; most of Proteus species known to cause disease in humans are associated with opportunistic infections [1].

Proteus mirabilis is ubiquitous in the natural environment. It is involved in the disintegration of the organic matter; it is also normal flora of the human intestinal tract, together with Escherichia coli and Klebsiella spp. where the E. coli is the most common [2]. It is an opportunistic bacterial pathogen which under favorable conditions causes many diseases such as urinary tract infections (UTIs), and especially with complicated UTI [3]. Usually, they affect the upper part of urinary tract causing infections such as cystitis, urolithiasis (kidney or bladder stones), and acute pyelonephritis and occasional cases of neonates or infants meningitis, bacteremia, wound infections, septicemia, and rheumatoid arthritis [4]. Its causes diseases by two steps, the first one involve colonization at the site of infection using fimbriae, and second by Ali and Yousif [5]. P. mirabilis expresses several virulence factor involved in uropathogenesis such as adhesions, swarming motility, urease, hemolysin, proteases, and lipopolysaccharide endotoxins [6].

Urease is an important virulence factor in the pathogenicity of $P$. mirabilis which causes obstruction of indwelling urinary catheter and kidney and bladder stones [7]. This multimeric nickel-metalloenzyme is encoded by urea-inducible urease gene cluster (ureDABCEFG) [8]. Urease operon transcription is positively activated by $u r e R$ a dimer of identical 293 amino acid polypeptides that bind urea resulting in the binding of protein avidly to both $u r e R$ and $u r e D$ promoters, then RNA polymerase is activated by $u r e R$ and thus will initiate transcription [9]. Because of the important role of urease in the pathogenicity of $P$. mirabilis, this study was aimed at investigating to detect the correlation between $u r e R$ and $u r e C$ in urease production.

\section{METHODS}

\section{Samples collection}

About 450 mid-stream urine samples have been collected from patients suffering from UTI from both genders at different age groups. All samples were cultured on MacConkey agar and incubated for $24 \mathrm{hrs}$ for primary isolation of $P$. mirabilis.

\section{Identification of $P$. mirabilis}

A suspected bacterial isolates that showed swarming phenomenon was further identified depending on conventional methods according to MacFaddin (2000) and molecular technique using $16 \operatorname{SrRNA}$ gene by polymerase chain reaction (PCR) technique [8].

\section{Phenotypic detection of urease}

A slant of urease agar test tubes were inoculated with bacterial isolates by stabbing and streaking method then incubated at $37^{\circ} \mathrm{C}$ for $24-48 \mathrm{hrs}$ change of media color from yellow to pink indicates a positive result [9].

\section{Molecular experiment}

Extraction of bacterial DNA

Extraction of template DNA from P. mirabilis isolates was carried out using boiling method as described by Sambrook and Russell (2001). Briefly, an overnight of brain heart infusion culture $(10 \mathrm{ml})$ of bacterial isolates were centrifuged at $6000 \mathrm{rpm} / 10$ minutes and the pellet was washed twice with Sodium Chloride-Tris-EDTA, 1 X solution $p H$ 8.0, Fisher BioReagents (STE) buffer $(0.058 \mathrm{~g}$ of $\mathrm{NaCl}, 0.015 \mathrm{~g}$ of Tris base and $0.004 \mathrm{~g}$ of ethylenediaminetetraacetic acid [EDTA] in $10 \mathrm{ml}$ of distilled water) then, $200 \mu \mathrm{l}$ of STE buffer was added, mixed well and heated to boiling for 10 minutes. Later on, a lysate was transferred to a water bath at $80^{\circ} \mathrm{C}$ for 5 minutes then incubated on ice bath for 5 minutes. The mixture was centrifuge for 30 minutes at 15,000 rpm, and the supernatant was transferred to a new Eppendorf tube and mixed with $0.7 \mathrm{ml}(\mathrm{V}: \mathrm{V})$ of isopropanol and incubated at $-4^{\circ} \mathrm{C}$ for overnight. The precipitated nucleic acid was recovered by centrifugation at 
$10,000 \mathrm{rpm} / 15$ minutes, and the pellet was washed with $70 \%$ ethanol and drained off till no trace of ethanol was seen, then $200 \mu \mathrm{l}$ of TrisEDTA buffer was added to re-suspend the DNA.

\section{Amplification of 16SrRNA gene}

Monoplex PCR technique has been carried out to amplify 16SrRNA using F-GAGTTTGATCCTGGCTCAG- and R-GGTTACCTTGTTACGACTT-. PCR mixture was used with a final volume of $20 \mu \mathrm{l}$ consisting of $5 \mu \mathrm{l}$ of master mix (2.5 U-iTag DNA polymerase, $2.5 \mathrm{mM}$ deoxynucleotide triphosphates, $\times 1$ reaction buffer and $\times 1$ gel loading buffer), $2 \mu$ of each forward and reverse, $5 \mu \mathrm{l}$ of DNA template, and $6 \mu \mathrm{l}$ of nuclease free water. PCR reaction was performed in PCR thermocycler (Biometra, USA) with the following conditions: $94^{\circ} \mathrm{C}$ for 2 minutes followed by 30 cycles of $94^{\circ} \mathrm{C}$ for 1 minute, $50.2^{\circ} \mathrm{C}$ for 1 minute, and $72^{\circ} \mathrm{C}$ for 1 minute with a final extension at $72^{\circ} \mathrm{C}$ for 5 minutes. The resulted amplicon was electrophoresis on $1 \%$ agarose gel stained with $0.5 \mu \mathrm{g} / \mathrm{ml}$ of ethidium bromide at $80 \mathrm{~V}$ for $1.5 \mathrm{hrs}$ and the gel was visualized by ultraviolet transilluminator unit and photographed [10]

\section{Amplification of ureR and ureC genes}

Duplex PCR was used to amplify ureR and ureC genes using F-GCGGTTTATCACGAAGGGGT- and R-TGAGTGCGAAATTGCGATGG- for ureR (designed in this study) and F-CCGGAACAGAAGTTGTCGCTGGA- and R-GGGCTCTCCTACCGACTTGATC- for ureC [10]. PCR mixture with a final volume of $20 \mu \mathrm{l}$ was prepared as described above. The conditions of amplification involved: $94^{\circ} \mathrm{C}$ for 2 minutes followed by 30 cycles of $94^{\circ} \mathrm{C}$ for 1 minute, $58^{\circ} \mathrm{C}$ for 1 minute for annealing and $72^{\circ} \mathrm{C}$ for 1 minute, and $72^{\circ} \mathrm{C}$ for 5 minutes. The resulted amplicon was electrophoresis as mentioned previously.

\section{RESULTS AND DISCUSSION}

The initial diagnosis that based on microscopic examination and characteristic of bacterial colonies on selective and differential culture media showed that out of 150 bacterial isolates only 36 isolates were belong to P. mirabilis which appeared as Gram-negative bacilli (pinkish red) arranged as non-capsulated and non-spore forming short rods or bacilli, while growth characteristics showed swarming phenomenon on blood agar that looks like concentric rings rising from one center. It also showed a transparent or pale yellow color with no lactose fermentation colonies when cultured on MacConkey agar. The results of biochemical tests that followed to confirm the initial diagnosis revealed that all P. mirabilis isolates were positive to methyl red test, citrate utilization, catalase, and urease tests; while the results were negative for oxidase, Voges-Proskauer, indole, and lactose fermentation tests; results of triple sugar iron test showed Alk/A with positive hydrogen sulfide and gas production. The results of molecular identification showed that 29 isolates (19.33\%) were belonged to P. mirabilis as the amplicon appeared with molecular weight 1500 bp as shown in Fig. 1.

The results of detection of P. mirabilis abilities to produce urease showed that all isolates $(100 \%)$ are able to hydrolyze urea by production of urease. Furthermore, the results of duplex PCR technique for amplification of ureR and $u r e C$ revealed that all isolates $100 \%$ possess both ureR and ureC by appearance of amplicon with molecular weight 359 and $533 \mathrm{bp}$, respectively, when electrophoresed on an agarose gel stained with ethidium bromide as shown in Fig. 2.

UTIs are still commonly diagnosed in outpatients as well as in hospitalized patients [11]. P. mirabilis is a normal flora of the human intestinal tract [12], it is an opportunistic pathogen which under a favorable conditions causes UTI, and it is commonly associated with complicated UTI, and they are important causative agents in community-acquired and nosocomial UTI and associated with $8.50 \%$ of UTI $[5,13]$.

This study revealed a variation in the results of biochemical tests that used for diagnosis of $P$. mirabilis, this may due to a variation in

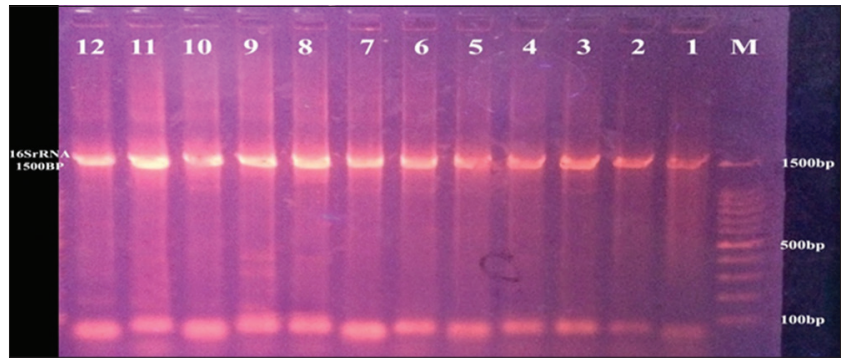

Fig. 1: Gel electrophoresis of polymerase chain reaction product of 16SrRNA of Proteus mirabilis (amplicon with $1500 \mathrm{bp}$ ). Lane M:

DNA marker (100 bp); Lane 1-12: Amplicon of 16SrRNA of P. mirabilis (1\% agarose, $80 \mathrm{~V}$ for 90 minutes)

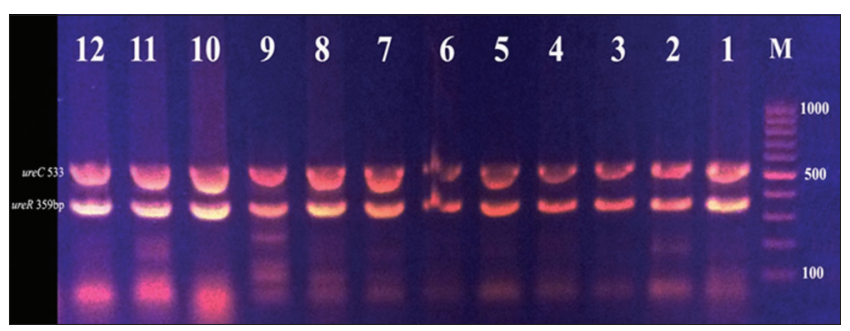

Fig. 2: Gel electrophoresis of duplex polymerase chain reaction product of ureR and ureC of Proteus mirabilis (amplicon with 359 and $533 \mathrm{bp}$, respectively). Lane M: DNA marker (100 bp); Lane 1-12: Amplicon of ureR and ureC of $P$. mirabilis (1\% agarose, $80 \mathrm{~V}$ for 90 minutes)

metabolic activity of bacterial isolates such as their negative results to oxidase may indicating that isolates use other pathways other than cytochrome $\mathrm{C}$ oxidase for respiratory process [13].

Several studies referred to using of $16 \operatorname{SrRNA}$ for identification of P. mirabilis isolated from ocular infections [14], cerebrospinal fluid $[15,16]$ who used specific primers for $16 \operatorname{SrRNA}$ gene to identify P. mirabilis and Proteus vulgaris that isolated from UTIs. 16SrRNA was described as a high discriminatory power for identification of bacteria and to differentiate between closely related genera because it exists in almost all bacteria, often existing as a gene cluster or operon, and also the function of this gene has not changed over time [17].

On the other hand, many studies demonstrate the high ability of P. mirabilis to produce urease $[18,19]$ and the study of Laurel et al. [20] found that all $P$. mirabilis isolates $(100 \%)$ showed strong production of urease.

Urease catalyzes the hydrolysis of urea to ammonia and carbonate then break down to carbon dioxide and another molecule of ammonia, as the following equation,

$\left(\mathrm{NH}_{2}\right)_{2} \mathrm{CO}+2 \mathrm{H}_{2} \mathrm{O} \stackrel{\text { Urease }}{\longrightarrow} \mathrm{CO}_{2}+\mathrm{H}_{2} \mathrm{O}+2 \mathrm{NH}_{3}$

Hence, it breaks down one molecule of urea to two molecules of ammonia and one carbon dioxide molecule, that causes nonphysiological alkalization of urine as the $\mathrm{pH}$ rise, that result in sedimentation of urinary components such as $\mathrm{Mg}^{+2}$ and $\mathrm{Ca}^{+2}$ which are soluble at slightly acidic or neutral $\mathrm{pH}$. As a result, struvite stones or carbonate apatite stones or both will form $[21,22]$. Urease also assists P. mirabilis to develop bacteriuria, cystitis, and kidney, and bladder stones [23].

A wide distribution of ureR and $u r e C$ among $P$. mirabilis was detected in several studies such as Lu et al. [24], MacFaddin [25], Mobley and Chippendale [26], and Mobley et al. [27]. Furthermore, Mobley and 
Chippendale (1990) showed that all P. mirabilis isolated from different clinical source produced a high amount of urease phenotypically compared to other bacteria and there was a concordance between phenotypic and molecular detection of urease activity. In addition, Nicholson et al. [28] and Ali and Yousif (2015) found that ureC gene is very abundant in P. mirabilis bacteria.

UreR is a member of the $A r a C$ family of transcriptional regulators and contains both DNA- and urea-binding domains. Two regulators of urease transcription have been characterized, ureR and H-NS (histonelike nucleoid structuring protein) [29]. UreR gene is transcribed in the opposite direction of UreDABCEFG; ureR binds the promoters of ure $R$ and ureD [30]. Transcription of the structural genes of urease is urea-inducible [31] where ureR acts as a positive regulator of urease activity and stimulates expression of urease genes in the presence of urea. H-NS is a negative regulator that represses $u r e R$ transcription. $\mathrm{H}-\mathrm{NS}$ binds to the poly (A) tracts located in the intergenic region between ureR and ureD and inhibits transcription of ureR [32], so, $u r e R$ is required for basal urease activity in the absence of urea, for induction of urease by urea, and for virulence of $P$. mirabilis in the urinary tract [33].

Nicholson [34] demonstrated that the transcription of the urease operon is regulated by ure $R$ a gene lies upstream from the seven accessory or structural genes and is transcribed from its own promoter in the direction opposite to the rest of the operon. Secondary regulation by a nitrogen regulatory system or catabolite repression does not appear. These data suggest that ureR governs the inducibility of $P$. mirabilis urease.

Urease gene cluster includes three structural genes, ureA, ureB, and $u r e C$, in addition to four accessory genes, ureD, ureE, ureF, and ureG. Urease apoenzyme is comprised a trimeric complex of the trimer ure $A B C$ (that is, three copies of each subunit) [35]. Activation of this urease apoenzyme requires incorporation of nickel ions into the metallocenter located in ureC [36]. The accessory proteins ureD, ureE, ureF, and ureG coordinate activation of the functional urease enzyme by mediating incorporation of the nickel ions into the active site [37].

UreC encodes the large subunit responsible for the production of urease enzyme of the P. mirabilis, and it is very highly conserved among all species, so it regarded as a diagnostic feature of the bacteria of P. mirabilis $[38,39]$. Yet, it is considered in this study as virulence factor which had been detected using PCR in addition to ureR.

\section{REFERENCES}

1. Abbott SL. Klebsiella, Enterobacter, Citrobacter, Serratia, Plesiomonas, and other Enterobacteriaceae. In: Murray PR, Baron EJ, Jorgensen JH, Landry ML, Pfaller MA, editors. Manual of Clinical Microbiology. $9^{\text {th }}$ ed. Washington, USA: ASM Press; 2007. p. 698-711.

2. Sekowska A, Janicka G, Wroblewska J, Kruszynska E. Prevalence of proteus mirabilis strains in clinical specimens and evaluation of their resistance to selected antibiotics. Pol Merkur Lekarski 2004:17(101):538-40.

3. Al-Duliami AA, Nauman NG, Hasan AS, Al-Azawi ZH. Virulence factors of Proteus mirabilis isolated from patients Otitis media in Baquba and its Peripheries. Diyala. J Med 2011;1(1):69-75.

4. Hasan AS, Al-Azawi ZH. Virulence factors of Proteus mirabilis isolated from patients otitis media in Baquba and its peripheries. Diyala J Med 2011;1(1):69-75

5. Ali HH, Yousif MG. Detection of some virulence factors genes of Proteus mirabilis that isolated from urinary tract infection. Int J Adv Res 2015;3(1):156-63.

6. Armbruster CE, Mobley HL. Merging mythology and morphology: The multifaceted lifestyle of Proteus mirabilis. Nat Rev Microbiol 2012;10(11):743-54.

7. Baron EJ, Peterson LR, Finegold SM. Bailey and Scott's Diagnostic Microbiology. $9^{\text {th }}$ ed. U.S.A: The C.V. Mosby Company; 1994.

8. Broomfield RJ, Morgan SD, Khan A, Stickler DJ. Crystalline bacterial biofilm formation on urinary catheters by urease-producing urinary tract pathogens: A simple method of control. J Med Microbiol 2009;58:1367-75.

9. Coker C, Poor CA, Le X, Mobley HL. Pathogenesis of Proteus mirabilis urinary tract infection. Microb Infect 2000b;2:1497-509.

10. Dattelbaum DJ, Lockatell VC, Johnson ED, Mobley TL. UreR, the transcriptional activator of the Proteus mirabilis urease gene cluster, is required for urease activity and virulence in experimental urinary tract infection. J Infect Immun 2003;71:1026-30.

11. D'Orazio SE, Thomas V, Collins CM. Activation of transcription at divergent urea-dependent promoters by the urease gene regulator UreR. Mol Microbiol 1996;21(3):643-55.

12. El-Baghdady KZ, Abooulwafa M, Ghobashy MO, Gebreel HM. Plasmid mediated virulence factors of some Proteus isolates. Egypt Acad J Biol Sci 2009;1(1):7-22.

13. Gendlina I, Gutman DM, Thomas V, Collins CM. Urea-dependent signal transduction by the virulence regulator UreR. J Biol Chem 2002;277(40):37349-58.

14. Huang HS, Chen J, Teng LJ, Lai MK. Use of polymerase chain reaction to detect Proteus mirabilis and Ureaplasma urealyticum in urinary calculi. J Formos Med Assoc 1999;98(12):844-50.

15. Island MD, Mobley HL. Proteus mirabilis urease: Operon fusion and linker insertion analysis of ure gene organization, regulation, and function. J Bacteriol 1995;177(19):5653-60.

16. Jabri E, Carr MB, Hausinger RP, Karplus PA. The crystal structure of urease from Klebsiella aerogenes. Science 1995;268(5213):998-1004

17. Jacobsen SM, Stickler DJ, Mobley HL, Shirtliff ME. Complicated catheter-associated urinary tract infections due to Escherichia coli and Proteus mirabilis. Clin Microbiol Rev 2008;21(1):26-59.

18. Jones BD, Mobley HL. Proteus mirabilis urease: Genetic organization, regulation, and expression of structural genes. J Bacteriol 1988;170(8):3342-9.

19. Jones SM, Yerly J, Hu Y, Ceri H, Martinuzzi R. Structure of Proteus mirabilis biofilms grown in artificial urine and standard laboratory media. J Microbiol Lett 2007;268(1):16-21.

20. Laurel SB, Janette MH, Xin L, Virginia CL, Stephanie DH, Richard JH, et al. Proteus mirabilis genes that contribute to pathogenesis of urinary tract infection: Identification of 25 signature tagged mutants attenuated at least 100 fold. J Infect Immun 2004;72:2922-38

21. Li X, Lockatell CV, Johnson AC, Emody L, Coleman N, Hughes C. The role of swarm cell differentiation and multicellular migration in the uropathogenicity of Proteus mirabilis. J Infect Dis 2004;169:1155-8.

22. Li X, Lockatell CV, Johnson DE, Mobley HL. Identification of MrpI as the sole recombinase that regulates the phase variation of MR/P fimbria, a bladder colonization factor of uropathogenic Proteus mirabilis. Mol Microbiol 2002;45(3):865-74.

23. Limanskii A, Minukhin V, Limanskaia O. Specific-specific detection of Proteus vulgaris and Proteus mirabilis by the polymerase chain reaction. J Microbiol Epidemiol Immun 2005;3:9-33.

24. Lu JJ, Perng CL, Lee SY, Wan CC. Use of PCR with universal primers and restriction endonuclease digestions for detection and identification of common bacterial pathogens in cerebrospinal fluid. J Clin Microbiol 2000;38(6):2076-80

25. MacFaddin JF. Biochemical Tests for Identification of Medical Bacteria. $1^{\text {st }}$ ed. Baltimore, USA: Williams and Wilkins; 2000.

26. Mobley LT, Chippendale GR. Hemagglutinin, urease and hemolysin production by Proteus mirabilis in clinical sources. J Infect Dis 1990;161:525-30.

27. Mobley HL, Island MD, Hausinger RP. Molecular biology of microbial ureases. Microbiol Rev 1995;59(3):451-80.

28. Nicholson EB, Concaugh EA, Foxall PA, Island MD, Mobley HL. Proteus mirabilis urease: Transcriptional regulation by UreR. J Bacteriol 1993;175(2):465-73.

29. Manoj K, Shikha C, Diljot KM, Neeru G, Sanjeevkumar C. Comparative antimicrobial efficacy evolution of new product elores against meropenem of gram-negative isolates. Asian J Pharm Clin Res 2015;8(4):251-4

30. O'Hara CM, Brenner FW, Miller JM. Classification, identification, and clinical significance of Proteus, Providencia, and Morganella. Clin Microbiol Rev 2000;13(4):534-46.

31. Park IS, Hausinger RP. Diethylpyrocarbonate reactivity of Klebsiella aerogenes urease: Effect of $\mathrm{pH}$ and active site ligands on the rate of inactivation. J Protein Chem 1993;12(1):51-6.

32. Patel JB. 16S rRNA gene sequencing for bacterial pathogen identification in the clinical laboratory. Mol Diagn 2001;6(4):313-21.

33. Poore CA, Mobley HL. Differential regulation of the Proteus mirabilis urease gene cluster by UreR and H-NS. Microbiology 2003;149:3383-94 
34. Ronald A. The etiology of urinary tract infection: Traditional and emerging pathogens. Am J Med 2002;113 Suppl 1A:14S-9.

35. Rozalski A, Torzewska A, Moryl M, Kwil I, Maszewska A, Ostrowska A, et al. Proteus sp. - An opportunistic bacterial pathogen-classification, swarming growth, clinical significance and virulence factors. Folia Biol Oecol 2013;8(1):1-17.

36. Sambrook J, Rusell DW. Molecular Cloning: A Laboratory Manual. $3^{\text {rd }}$ ed. New York, N.Y: Cold Spring Harbor, Cold Spring Harbor Laboratory Press; 2001

37. Samira N, Abouddihaj B, Nezha B, Kaotar N, Mohamed T,
Abderraouf $\mathrm{H}$, et al. Occurrence of carbapenemases and extendedspectrum beta-lactamses in uropathogenic enterobacterialceae isolated from a community setting, settat, morocco. Asian J Pharm Clin Res 2017;10(1):211-5

38. Schabereiter-Gurtner C, Maca S, Rollenke S. 16S rRNA-based identification of bacteria from conjunctival swabs by PCR and DGGE fingerprinting. Invest Ophthalmol J Vis Sci 2001;42:1164.

39. Shoket H, Ali S, Gupta RK, Mishra VK. Occurrence of Proteus mirabilis associated with vegetable samples in Dehradun, Uttarakhand, India. Int J Curr Microbiol Appl Sci 2014;3(7):958-61. 